Article

\title{
Antibacterial Activity of Emulsified Pomelo (Citrus grandis Osbeck) Peel Oil and Water-Soluble Chitosan on Staphylococcus aureus and Escherichia coli
}

\author{
Guan-Wen Chen ${ }^{1}$, Yu-Hsin Lin ${ }^{2, * \mathbb{B}}$, Chia-Hua Lin $^{3}$ and Hsiao-Chin Jen ${ }^{4}$ \\ 1 Department of Food Science, National Taiwan Ocean University, No. 2 Pei-Ning Rd., Keelung 202, Taiwan; \\ chengw@mail.ntou.edu.tw \\ 2 Department of Food Technology and Marketing, Taipei University of Marine Technology, No. 212, Sec. 9, \\ Yan Ping N. Rd., Taipei 111, Taiwan \\ 3 Department of Biotechnology, National Formosa University, No. 64, Wunhua Rd, Yunlin 632, Taiwan; \\ vicchlin@nfu.edu.tw \\ 4 Department of Health Promotion and Gerontological Care, Taipei University of Marine Technology, No. 212, \\ Sec. 9, Yan Ping N. Rd., Taipei 111, Taiwan; f1216@mail.tcmt.edu.tw \\ * Correspondence: yhlin@mail.tcmt.edu.tw; Tel.: +886-228-109-999 (ext. 3405)
}

Academic Editor: Daniela Rigano

Received: 18 March 2018; Accepted: 5 April 2018; Published: 6 April 2018

\begin{abstract}
This study utilized pomelo steam distillation to isolate pomelo peel essential oil. The constituents were then analyzed through gas chromatography-mass spectrometry (GC-MS), and the antibacterial activity of the essential oil emulsions at different homogenizer speed conditions and concentrations of water-soluble chitosan (degree of acetylation, DA $=54.8 \%$ ) against $S$. aureus and E. coli was examined. Analysis of the essential oil composition identified a total of 33 compounds with the main constituent, limonene accounting for $87.5 \%(940.07 \mathrm{mg} / \mathrm{g})$ of the total. The pomelo peel oil was emulsified through homogenization at $24,000 \mathrm{rpm}$, resulting in a minimal inhibitory concentration (MIC) for E. coli that was 1.9 times lower than that of the essential oil without homogenization. In addition, a mixture of $0.4 \%$ essential oil emulsion and $0.03 \%$ water-soluble chitosan had the strongest synergetic antibacterial effect on S. aureus and E. coli at $\mathrm{pH}$ 7.4. In comparison with chitosan alone, the MIC value of this mixture was significantly 2.4 and 2.5 times lower. Hence, this study suggests using a mixture of emulsified pomelo peel oil and water-soluble chitosan to develop a novel natural food preservative, and that the processability of food, as well as the economic value of the byproducts of the Taiwan Matou pomelo and chitosan, could be increased.
\end{abstract}

Keywords: essential oil; pomelo; antibacterial activity; emulsified essential oil; water-soluble chitosan

\section{Introduction}

Food safety is closely related to public health, a topic that has gained increasing attention. According to current knowledge, ingesting food contaminated by pathogenic microorganisms, such as Staphylococcus aureus and Escherichia coli, may increase health risks. To prevent food from being contaminated by microorganisms, chemosynthetic preservatives are prevalent in the food industry [1]. However, as consumers have become more aware of food safety issues, the demand for food free of chemical preservatives has gradually grown. Therefore, the development of a natural and safe antimicrobial agent has become more important.

Citrus grandis Osbeck, also known as pomelo, is a popular seasonal fruit in Taiwan. It is regularly consumed in Asian countries as a whole fruit, juice, or preserved snack [2]. The annual yield of 
pomelo in Taiwan is 70,000 $\mathrm{t}$ [3]. The pomelo is a popular fruit for Chinese festivals; however, they are sometimes overproduced, have slow sales and are discarded after festivals. This fruit, and its processed products, produce considerable waste or byproducts during eating or processing, such as peels, seeds, and pulp, which account for approximately $50 \%$ of the original fruit weight [4]. These byproducts could be a valuable source for functional food ingredients, such as flavonoids, dietary fibers, and essential oils [5]. Essential oil is the most important byproduct of citrus processing and is usually obtained from the peels. Essential oils are mixtures of aromatic volatile compounds produced by the secondary metabolism of plants and they can be used as natural antimicrobials [6]. Several reports have addressed the antimicrobial activity of essential oils, as well as the use of essential oils as antimicrobial agents in food products. However, many potential technological challenges remain associated with incorporating essential oils into food products, due to their low water solubility, poor chemical stability, and volatile nature [7]. In recent years, many studies have used emulsification or nanotechnology to improve the characteristics of essential oils to enhance its usability and stability, in order to enhance its applicability to food [8,9]. However, research into the antimicrobial activity of emulsified citrus essential oil under different homogenization conditions is limited.

Chitosan, being produced from a major waste product of the marine food processing industry, is widely available. It is a biodegradable, nontoxic biopolymer of glucosamine and $\mathrm{N}$-acetylglucosamine that is commercially produced by deacetylating chitin, the main structural component of crustacean shells. Chitosan exhibits a wide array of potential biological activities, such as antitumor, immunostimulatory, antibacterial, and antifungal activities [10,11]. The antimicrobial activity of chitosan against a variety of bacteria and fungi is known to be due to its polycationic nature [11,12]. However, its antibacterial activity is limited at a $\mathrm{pH}$ higher than 6.5, when chitosan starts to lose its positive charge and become insoluble in water $[13,14]$. Thus, many researchers have focused on the preparation of chitosan and chitosan derivatives that are soluble in water over a wider $\mathrm{pH}$ range through enzymatic and acid hydrolysis. In addition, chitosan is widely used as an antimicrobial agent when blended with other natural polymers [10,15]. However, research into the antimicrobial activity of water-soluble chitosan with about 50.0\% degree of acetylation blended with citrus essential oil emulsion is limited.

This study used Taiwan Matou pomelo peel as the raw material and performed industrially safe and nontoxic steam distillation to obtain the essential oil. The main composition was analyzed, and the effect of essential oil emulsions after different homogenization conditions was investigated, Then, the essential oil was blended with different concentrations of water-soluble chitosan with about $50.0 \%$ degree of acetylation and the antimicrobial activity was examined. Common foodborne pathogenic bacteria, the gram-negative E. coli and the gram-positive S. aureus, were used as antimicrobial index strains. An emulsion mixture of pomelo peel essential oil and water-soluble chitosan is expected to be developed in the future, to be used in the food and catering industries as a natural water-soluble germicide or food preservative. This will increase the economic value of Taiwan Matou pomelo peel and chitin wastes.

\section{Results and Discussion}

\subsection{Analysis of Pomelo Peel Essential Oil Composition}

Essential oil was obtained from the fresh peel of the Taiwan Matou cultivar of the pomelo (Citrus grandis [L.] Osbeck cv. Matou Wentan) through steam distillation. The essential oil composition was analyzed through GC-MS, and 33 compounds were identified. According to gas chromatography (GC) quantitative analysis, the main constituents in descending order of content were limonene $(87.5 \%$, $940.07 \mathrm{mg} / \mathrm{g})$, myrcene $(3.1 \%, 23.65 \mathrm{mg} / \mathrm{g}), \beta$-pinene $(2.7 \%, 13.53 \mathrm{mg} / \mathrm{g}), \alpha$-pinene $(6.0 \%, 4.66 \mathrm{mg} / \mathrm{g})$, cis-linalool oxide (f) $(0.6 \%, 3.82 \mathrm{mg} / \mathrm{g})$, and linalool $(0.4 \%, 2.48 \mathrm{mg} / \mathrm{g})$ (Table 1$)$. This is similar to the findings of previous investigations into pomelo peel oils, which reported that limonene (93.9\%), myrcene $(1.9 \%), \beta$-pinene $(1.1 \%)$, and $\alpha$-pinene $(0.5 \%)$ were the chief components [16]. Previous studies 
have shown that limonene (62.0-95.4\%) was the principal constituent of pomelo peel oils [16,17]. Differences in the limonene content of the essential oil of pomelo peel may be due to differences in the growth environment, provenance, isolation conditions, and the part of the plant where the oil was obtained [16,17].

Table 1. Constituents of pomelo peel oil isolated by steam distillation.

\begin{tabular}{|c|c|c|c|c|}
\hline \multirow{2}{*}{ Peak No. } & \multirow{2}{*}{ Constituents } & \multirow{2}{*}{ K.I. $^{\mathrm{a}}$} & \multicolumn{2}{|c|}{ Concentration } \\
\hline & & & Relative(\%) & Absolute (mg/g) \\
\hline 1 & $\alpha$-pinene & 938 & 0.8 & 4.66 \\
\hline 2 & $\beta$-pinene & 980 & 2.7 & 13.53 \\
\hline 3 & myrcene & 991 & 3.1 & 23.65 \\
\hline 4 & $\alpha$-phellandrene & 1002 & 0.1 & \\
\hline 5 & limonene & 1031 & 87.5 & 940.07 \\
\hline 6 & trans- $\beta$-ocimene & 1048 & 0.4 & \\
\hline 7 & $\gamma$-terpinene & 1061 & 0.1 & 0.24 \\
\hline 8 & cis-linalool oxide (f) & 1072 & 0.6 & 3.82 \\
\hline 9 & $\alpha$-terpinolene & 1086 & 0.1 & \\
\hline 10 & trans-linalool oxide (f) & 1089 & 0.3 & 2.15 \\
\hline 11 & linalool & 1098 & 0.4 & 2.48 \\
\hline 12 & trans- $p$-2,8-mentha-dien-1-ol & 1121 & 0.0 & \\
\hline 13 & cis-limonene oxide & 1135 & 0.0 & \\
\hline 14 & trans-limonene oxide & 1140 & 0.0 & \\
\hline 15 & $\beta$-terpineol & 1147 & - & \\
\hline 16 & terpinen-4-ol & 1176 & 0.1 & \\
\hline 17 & $\alpha$-terpineol & 1188 & 0.3 & 2.18 \\
\hline 18 & trans-carveol & 1216 & 0.0 & \\
\hline 19 & nerol & 1228 & 0.1 & \\
\hline 20 & cis-carveol & 1229 & 0.1 & \\
\hline 21 & neral & 1237 & 0.1 & \\
\hline 22 & carvone & 1243 & 0.0 & \\
\hline 23 & geraniol & 1250 & 0.1 & \\
\hline 24 & geranial & 1266 & 0.2 & \\
\hline 25 & neryl acetate & 1363 & 0.0 & 0.072 \\
\hline 26 & geranyl acetate & 1380 & 0.0 & 0.25 \\
\hline 27 & $\beta$-elemene & 1390 & 0.0 & \\
\hline 28 & $\alpha$-cedrene & 1410 & 0.2 & \\
\hline 29 & $\beta$-caryophyllene & 1420 & 0.2 & \\
\hline 30 & germacrene-D & 1486 & 0.4 & \\
\hline 31 & $\delta$-cadinene & 1523 & 0.0 & \\
\hline 32 & (E)-nerolidol & 1561 & 0.0 & \\
\hline 33 & caryophyllene oxide & 1582 & 0.0 & \\
\hline
\end{tabular}

a Relative Kovat's indices, experimental: n-alkanes (C9-C24) were used as reference points to calculate relative retention indices.

\subsection{Antibacterial Activity of Essential Oil}

The solutions of essential oil at different concentrations with or without homogenization were used for antibacterial activity tests involving $S$. aureus and E. coli (Table 2).

Table 2. Effect of homogenization speed and concentration of emulsified pomelo peel oil on the viability of $S$. aureus and E. coli $(\log C F U / \mathrm{mL})$ a,b.

\begin{tabular}{|c|c|c|c|c|c|}
\hline \multirow{2}{*}{ Bacteria } & \multirow{2}{*}{ rpm } & \multicolumn{4}{|c|}{ Concentration of Essential Oil (\%) } \\
\hline & & $0^{c}$ & 0.1 & 0.2 & 0.4 \\
\hline \multirow[t]{3}{*}{ S. aureus } & 0 & $9.00 \pm 0.14 \mathrm{Ax}$ & $8.32 \pm 0.07^{\mathrm{Bx}}$ & $8.07 \pm 0.11^{\mathrm{BCx}}$ & $7.97 \pm 0.23^{C x}$ \\
\hline & 13,500 & $8.97 \pm 0.06^{\mathrm{Ax}}$ & $8.21 \pm 0.09 \mathrm{Bx}$ & $8.16 \pm 0.02 \mathrm{BCx}$ & $8.07 \pm 0.07 \mathrm{Cx}$ \\
\hline & 24,000 & $8.97 \pm 0.06^{\mathrm{Ax}}$ & $8.20 \pm 0.03^{\mathrm{Bx}}$ & $8.05 \pm 0.11^{C x}$ & $7.81 \pm 0.01 \mathrm{Dx}$ \\
\hline \multirow[t]{3}{*}{ E. coli } & 0 & $9.03 \pm 0.07 \mathrm{Ax}$ & $8.44 \pm 0.15^{\mathrm{Bx}}$ & $8.25 \pm 0.03^{B C x}$ & $8.18 \pm 0.13^{C x}$ \\
\hline & 13,500 & $8.95 \pm 0.15^{\mathrm{Ax}}$ & $8.49 \pm 0.03^{\mathrm{Bx}}$ & $8.26 \pm 0.14^{C x}$ & $7.85 \pm 0.06^{\mathrm{Dy}}$ \\
\hline & 24,000 & $8.95 \pm 0.15^{\mathrm{Ax}}$ & $8.38 \pm 0.06^{\mathrm{Bx}}$ & $7.91 \pm 0.12$ Сy & $7.72 \pm 0.03^{C z}$ \\
\hline
\end{tabular}

${ }^{a}$ Means within a row with different superscripts (A-D) differ significantly $(p<0.05), \mathrm{n}=3$. ${ }^{\mathrm{b}}$ Means within a column with different superscripts $(\mathrm{x}-\mathrm{z})$ differ significantly $(p<0.05), \mathrm{n}=3 .{ }^{\mathrm{c}} 1 \%$ Tween 20 solution without homogenization. 
Tween 20 was utilized as a surfactant to facilitate emulsion formation and stability, and 1\% Tween 20 aqueous solution without essential oil served as the control group. The antibacterial effect increased with the essential oil concentration. The antibacterial effect of the unhomogenized essential oil on S. aureus and E. coli was the strongest when the concentration was $0.4 \%(4 \mu \mathrm{L} / \mathrm{mL})$; the total bacterial counts of $S$. aureus $(7.97 \pm 0.23 \mathrm{CFU} / \mathrm{mL})$ and E. coli $(8.18 \pm 0.13 \mathrm{CFU} / \mathrm{mL})$ were lower than those of the control group by 1.03 and $0.85 \log \mathrm{CFU} / \mathrm{mL}$, respectively. According to the results, the pomelo peel essential oil had a greater inhibitory effect on $S$. aureus than on E. coli. This result is consistent with previous findings on antibacterial citrus essential oils and suggests that the essential oil and its compounds have a stronger inhibitory effect on gram-positive bacteria than on gram-negative bacteria [6,18]. In addition, the antibacterial effects observed at different homogenizer speeds and the same essential oil concentration indicate that the homogenizer speed has no significant effect $(p<0.05)$ on the antibacterial activity of $S$. aureus, though the antibacterial effect increases with the homogenizer speed. When the essential oil concentration was increased to $0.4 \%(v / v)$ and the homogenizer speed was $24,000 \mathrm{rpm}$, the total bacterial counts of $E$. coli were lower than those of the unhomogenized group and the 13,500 rpm group by 0.46 and $0.33 \log$ CFU/mL, respectively (Table 2). The MIC values for $S$. aureus and E. coli were calculated from the regression curve between various essential oil concentrations at different homogenizer speeds $(0,13,500$, and 24,000 rpm) and the residual bacterial count. The MIC values of the unhomogenized group and 24,000 rpm group for S. aureus were $0.29 \%$ $(2.9 \mu \mathrm{L} / \mathrm{mL})$ and $0.27 \%(2.7 \mu \mathrm{L} / \mathrm{mL})$, respectively. For E. coli, the MIC value of the essential oil emulsion homogenized at $24,000 \mathrm{rpm}$ was $0.25 \%(2.5 \mu \mathrm{L} / \mathrm{mL})$, whereas that of the unhomogenized group was $0.49 \%(4.9 \mu \mathrm{L} / \mathrm{mL})$ (Table 5). According to the results of this study, homogenization at 24,000 rpm markedly enhanced the inhibitory effect of the essential oil emulsion on E. coli, with the MIC being 1.9 times lower than that of the essential oil without homogenization. In a study by Inouye et al., the MIC value of citron oil, and its key compound limonene, for S. aureus and E. coli was $>0.32 \%(w / v)[6]$. Additionally, Moghimi et al. found that the MIC value of a nanoemulsion of Thymus daenensis essential oil against $E$. coli was 10 times higher than that of pure essential oil, with the MIC values being $0.4 \mathrm{mg} / \mathrm{mL}$ and $4.0 \mathrm{mg} / \mathrm{mL}$, respectively [9]. Emulsification enhances the antibacterial effect of essential oil on E. coli, which may be related to the speed of homogenization. The higher the homogenizer speed is, the more complete the emulsification; the size of the oil droplets decreases, the stability of the oil droplets is enhanced, and the oil droplets are uniformly dispersed in the overall solution system, which enhances the ability of the oil to permeate the hydrophilic pericellular membrane of the gram-negative bacterium E. coli and thus improves antibacterial activity [8,9]. The results of this study are in agreement with previous studies, indicating that the antibacterial effects are greatly improved through the conversion of flavor or essential oils (e.g., oregano oil and D-limonene) into nanoemulsions $[8,19]$.

\subsection{Antibacterial Activity of Water-Soluble Chitosan}

Water-soluble chitosan (DA $=54.80 \%$ ) was prepared by using acetic anhydride acetylation, and the antibacterial effects of water-soluble chitosan $(\mathrm{pH} 7.4)$ at different concentrations $(0.01 \%, 0.03 \%, 0.05 \%$, and $0.1 \%$ ) on S. aureus and E. coli were measured (Table 3).

Table 3. Effect of chitosan concentration on the viability of S. aureus and E. coli (Log CFU/mL) ${ }^{\mathrm{a}, \mathrm{b}}$.

\begin{tabular}{lccccc}
\hline \multirow{2}{*}{ Bacteria } & \multicolumn{5}{c}{ Concentration of Chitosan (\%) } \\
\cline { 2 - 6 } & Control & $\mathbf{0 . 0 1}$ & $\mathbf{0 . 0 3}$ & $\mathbf{0 . 0 5}$ & $\mathbf{0 . 1}$ \\
\hline S. aureus & $9.05 \pm 0.04^{\mathrm{Ax}}$ & $8.56 \pm 0.03^{\mathrm{Bx}}$ & $8.53 \pm 0.02^{\mathrm{Bx}}$ & $7.93 \pm 0.16^{\mathrm{Cx}}$ & $8.09 \pm 0.15^{\mathrm{Cx}}$ \\
E. coli & $9.01 \pm 0.01^{\mathrm{Ax}}$ & $8.57^{\mathrm{B}} \pm 0.04^{\mathrm{Bx}}$ & $8.54 \pm 0.01^{\mathrm{Bx}}$ & $8.18 \pm 0.07^{\mathrm{Cx}}$ & $7.94 \pm 0.05^{\mathrm{Dx}}$ \\
\hline
\end{tabular}

${ }^{a}$ Means within a row with different superscripts (A-D) differ significantly $(p<0.05), \mathrm{n}=3 .{ }^{\mathrm{b}}$ Means within a column with different superscripts $(\mathrm{x})$ differ significantly $(p<0.05), \mathrm{n}=3$. 
The results showed that the antibacterial effect of water-soluble chitosan on S. aureus and E. coli increased with the concentration of chitosan. At a concentration of $0.1 \%$, water-soluble chitosan exerted the strongest antibacterial effect on S. aureus and E. coli. The total bacterial counts of S. aureus and E. coli were lower than those of the control group by 0.96 and $1.07 \log C F U / \mathrm{mL}$, respectively (Table 3). The findings of this study are similar to those reported by Chen, et al., who used water-soluble chitosan with a DA of 50\%; when the concentration was $1,000 \mathrm{ppm}$, the bacterial count of S. aureus was reduced by about $1.0 \log \mathrm{CFU} / \mathrm{mL}$ after $12 \mathrm{~h}$ of cultivation [13]. In addition, Omura et al. reported that once the degree of $\mathrm{N}$-acetylation reached approximately $55 \%$, chitosan had a good inhibitory effect on S. aureus and E. coli, with an MIC value of $>0.1 \%(w / v)$ (equivalent to $>1000 \mathrm{ppm})$ [14]. The antibacterial effectiveness of chitosan has been demonstrated against both gram-positive and gram-negative bacteria, with an MIC range of 100 to $2000 \mathrm{ppm}$ [20]. In the current study, the MIC values for S. aureus and E. coli were calculated from the regression curve between the concentration of water-soluble chitosan and residual bacterial count to be $0.046 \%$ and $0.086 \%$, respectively (Table 5).

\subsection{Antibacterial Activity of Essential Oil Emulsion and Water-Soluble Chitosan}

The water-soluble chitosan at different concentrations was mixed with a $0.4 \%$ essential oil emulsion (homogenized at 24,000 rpm), and the antibacterial effects of the combination of the essential oil emulsion and water-soluble chitosan on S. aureus and E. coli were measured (Table 4).

Table 4. Effect of chitosan concentration in $0.4 \%$ emulsified pomelo peel oil on the viability of S. aureus and E. coli $(\log \mathrm{CFU} / \mathrm{mL})^{\mathrm{a}, \mathrm{b}}$.

\begin{tabular}{lcccccc}
\hline \multirow{2}{*}{ Bacteria } & \multicolumn{7}{c}{ Concentration of Chitosan (\%) } \\
\cline { 2 - 7 } & Control & $\mathbf{0}$ & $\mathbf{0 . 0 1}$ & $\mathbf{0 . 0 3}$ & $\mathbf{0 . 0 5}$ & $\mathbf{0 . 1}$ \\
\hline S. aureus & $9.16 \pm 0.09^{\mathrm{Ax}}$ & $8.10 \pm 0.07^{\mathrm{Bx}}$ & $7.19 \pm 0.22^{\mathrm{Cx}}$ & $6.76 \pm 0.17^{\mathrm{Dx}}$ & $6.82 \pm 0.13^{\mathrm{Dx}}$ & $6.99 \pm 0.26^{\mathrm{CDx}}$ \\
E. coli & $9.18 \pm 0.01^{\mathrm{Ax}}$ & $7.93 \pm 0.01^{\mathrm{By}}$ & $7.39 \pm 0.15^{\mathrm{Cx}}$ & $6.92 \pm 0.26^{\mathrm{Dx}}$ & $6.63 \pm 0.06^{\mathrm{Ex}}$ & $7.10 \pm 0.16^{\mathrm{DEx}}$ \\
\hline
\end{tabular}

${ }^{a}$ Means within a row with different superscripts (A-E) differ significantly $(p<0.05), \mathrm{n}=3 .{ }^{\mathrm{b}}$ Means within a column with different superscripts $(x-y)$ differ significantly $(p<0.05), \mathrm{n}=3$.

The antibacterial effects of chitosan at concentrations of $0,0.01 \%, 0.03 \%, 0.05 \%$, and $0.1 \%$ on S. aureus were lower than those of the control group by 1.06, 1.97, 2.40, 2.34, and $2.17 \log \mathrm{CFU} / \mathrm{mL}$, respectively; the effects on E. coli were lower by $1.25,1.79,2.26,2.55$, and $2.08 \log \mathrm{CFU} / \mathrm{mL}$, respectively (Table 4). The results showed that the combination of the essential oil emulsion and water-soluble chitosan can significantly enhance the antibacterial effect on S. aureus and E. coli. In addition, in comparison with the antibacterial effect of only water-soluble chitosan (no emulsified essential oil) on S. aureus, the MIC value of the combination of the essential oil emulsion and water-soluble chitosan was 2.4 times higher, with the MIC values being $0.046 \%$ and $0.019 \%$, respectively (Table 5). Moreover, the MIC value of the combination of the essential oil emulsion and water-soluble chitosan on E. coli was 2.5 times higher, with the MIC value being $0.034 \%$, compared with $0.086 \%$ of chitosan alone (Table 5). This result may be related to a synergistic effect of water-soluble chitosan and emulsified pomelo peel oil on bacterial activity. This coincides with the results of Feyzioglu and Tornuk, who suggested that chitosan nanoparticles loaded with essential oil from summer savory provide significant reductions in bacteria (E. coli O157:H7, Listeria monocytogenes, and S. aureus) in comparison with chitosan nanoparticles alone [21]. However, in the current study, when the water-soluble chitosan concentration in the $0.4 \%$ essential oil emulsion was $0.1 \%$, the antibacterial effect on $S$. aureus and E. coli was lower than that in the $0.03 \%$ and $0.05 \%$ groups. However, the differences were not significant (Table 4), which may be because the high concentration of chitosan reduced the contact between the hydrophobic essential oil compound and the cell wall of the bacteria, obstructing the channels for the essential oil compound to enter the bacteria. Thus, the essential oil compound could not permeate the bacterial cells, resulting in lower bacteriostatic activity against $S$. aureus and E. coli [22]. 
Table 5. Minimum inhibitory concentration (MIC) of emulsified pomelo peel oil and chitosan against $S$. aureus and E. coli.

\begin{tabular}{lccccc}
\hline \multirow{3}{*}{ Bacteria } & \multicolumn{5}{c}{ MIC } \\
\cline { 2 - 6 } & $\mathbf{0 ~ ( \mathbf { r p m } )}$ & $\mathbf{1 3 , 5 0 0}(\mathbf{r p m})$ & $\mathbf{2 4 , 0 0 0}(\mathbf{r p m})$ & $\mathbf{+ 0} \%$ E.O. & $\mathbf{+ 0 . 4 \%}$ E.O. \\
\cline { 2 - 6 } & 0.29 & $>0.29$ & 0.27 & 0.046 & 0.019 \\
S. aureus & 0.49 & 0.34 & 0.25 & 0.086 & 0.034 \\
E. coli & & & &
\end{tabular}

The $0.4 \%$ pomelo peel essential oil emulsion mixed with $0.03 \%$ water-soluble chitosan had a significant antibacterial effect on S. aureus and E. coli $(p<0.05)$ (Table 4$)$. In addition, the MIC values of this mixture for S. aureus and E. coli were $0.019 \%$ and $0.034 \%$, respectively. As such, the MIC value of this mixture for $S$. aureus was higher than that of the $0.01 \%$ water-soluble chitosan, but the value for E. coli was nearest to the $0.03 \%$ water-soluble chitosan. Therefore, we further analyzed the antibacterial activity and stability of this mixture at various $\mathrm{pH}$ values.

\subsection{Antibacterial Activity of the Combination of Essential Oil and Chitosan at Various $p H$ Values}

When the culture media at $\mathrm{pH} 5.5,7.4$, and 8.5 were mixed only with the $0.4 \%$ essential oil emulsion, the $S$. aureus inhibition rates were $81.20 \%, 90.04 \%$, and $95.10 \%$, respectively, suggesting that the $\mathrm{pH} 8.5$ basic essential oil emulsion has the highest inhibitory effect on S. aureus (Table 6).

Table 6. Effects of adding emulsified pomelo peel oil, chitosan, and E.O.-chitosan in broths of different $\mathrm{pH}$ values on the inhibitory percentage (\%) of S. aureus and E. coli ${ }^{\mathrm{a}, \mathrm{b}}$.

\begin{tabular}{|c|c|c|c|c|}
\hline \multirow{2}{*}{ Bacteria } & \multirow{2}{*}{ Sample } & \multicolumn{3}{|c|}{$\mathrm{pH}$} \\
\hline & & $5.5^{c}$ & $7.4^{d}$ & $8.5^{\mathrm{e}}$ \\
\hline \multirow{3}{*}{ S. aureus } & $0.4 \%$ E.O. & $81.20 \pm 2.22^{C x}$ & $90.04 \pm 1.04^{\mathrm{By}}$ & $95.10 \pm 0.65 \mathrm{Ax}$ \\
\hline & $0.03 \%$ chitosan & $85.47 \pm 1.33 \mathrm{Ax}$ & $65.26 \pm 2.09 \mathrm{Bz}$ & $61.83 \pm 1.90$ By \\
\hline & $0.4 \%$ E.O. $+0.03 \%$ chitosan & $82.58 \pm 0.77^{C x}$ & $99.48 \pm 0.25 \mathrm{Ax}$ & $97.46 \pm 0.94^{\mathrm{Bx}}$ \\
\hline \multirow{3}{*}{ E. coli } & 0.4\% E.O. & $78.11 \pm 0.40^{\text {By }}$ & $92.70 \pm 0.62$ Ay & $71.29 \pm 2.56^{\mathrm{Cy}}$ \\
\hline & $0.03 \%$ chitosan & $76.04 \pm 1.63$ Аy & $62.61 \pm 3.70^{\mathrm{Bz}}$ & $66.06 \pm 6.71 \mathrm{ABy}$ \\
\hline & $0.4 \%$ E.O. $+0.03 \%$ chitosan & $91.68 \pm 4.56^{\mathrm{Bx}}$ & $99.06 \pm 0.07 \mathrm{Ax}$ & $95.06 \pm 0.63 \mathrm{ABx}$ \\
\hline
\end{tabular}

\footnotetext{
${ }^{a}$ Means within a row with different superscripts $(A-C)$ differ significantly $(p<0.05), n=3 .{ }^{b}$ Means within a column with different superscripts $(\mathrm{x}-\mathrm{z})$ differ significantly $(p<0.05), \mathrm{n}=3 .{ }^{\mathrm{c}}$ Zeta potential of chitosan is $5.4 \mathrm{mV}$. ${ }^{\mathrm{d}}$ Zeta potential of chitosan is $-3.8 \mathrm{mV}$. ${ }^{\text {e }}$ Zeta potential of chitosan is $-3.2 \mathrm{mV}$.
}

This result is similar to the result of Hoque et al. [23]. Clove isolation exhibited higher antibacterial activity against $S$. aureus at $\mathrm{pH} 9.0$, compared with $\mathrm{pH} 5.0$ and 7.0. In addition, essential clove oil exhibited higher antibacterial activity against gram-positive bacteria (L. monocytogenes) at $\mathrm{pH} 9.0$ than at $\mathrm{pH} 5.0$ and 7.0 [23]. Regarding the effect of the $\mathrm{pH}$ value on the activity of essential oil, the $\mathrm{pH}$ value may influence charge modification on the cell membrane surface; thus, the charged constituents of the essential oil bind to the microorganism cell membrane, which may damage the cells [24]. However, the E. coli inhibition rates of the essential oil emulsion alone were $78.11 \%, 92.7 \%$, and $71.29 \%$, indicating that neutral ( $\mathrm{pH}$ 7.4) essential oil emulsions have the highest inhibitory effect, followed by acidic emulsions. Generally, a low $\mathrm{pH}$ increases the hydrophobicity of the essential oil, and the resistance of bacteria to this essential oil and its constituents decreases with the $\mathrm{pH}$ value; thus, it is easier for essential oils to dissolve in the lipids of the bacterial cell membrane [25]. However, according to findings regarding citrus essential oils, the principal component limonene, which belongs to the family of cyclic monoterpene hydrocarbons, is believed to accumulate in the bacterial cell membrane, which results in the loss of membrane integrity and leads to dissipation of the proton motive force [26]. Previous studies on the inactivation of $E$. coli by limonene demonstrated that it targets the phospholipids of 
cytoplasmic membranes and the lipopolysaccharide fraction of the cell wall at $\mathrm{pH} 7.0$ and $\beta$-sheet protein out of the membrane at $\mathrm{pH} 4.0$, which results in sublethal injury in the outer and cytoplasmic membranes [27]. Furthermore, water-soluble chitosan at $0.03 \%$ and $\mathrm{pH} 5.5$ had the highest inhibitory effect; the S. aureus inhibition rate was $85.47 \%$, and the E. coli inhibition rate was $76.04 \%$ (Table 6). For water-soluble chitosan in TSB solutions at different $\mathrm{pH}$ values $(5.5,7.4$, and 8.5$)$, the particle surface charge values were $5.4,-3.8$, and $-3.2 \mathrm{mV}$, respectively (Table 6). Cationic $\left(\mathrm{NH}^{3+}\right)$ forms of chitosan are present in acidic $\mathrm{pH}$, while in neutral and basic $\mathrm{pH}, \mathrm{NH}_{2}$ groups are present. The number of $\mathrm{NH}_{2}$ groups is related not only to chitosan concentration but also to the degree of acetylation, that is, it diminished when the degree of acetylation increased [28]. This result indicates that water-soluble chitosan is positively charged at $\mathrm{pH} 5.5$; thus, the inhibitory effect on $\mathrm{S}$. aureus and E. coli is significantly $(p<0.05)$ higher than that at pH 7.4 and 8.5. This finding is similar to that of Xie et al. [29]. For the mixture of the essential oil emulsion and water-soluble chitosan, the $S$. aureus inhibition rate $(82.58 \%)$ of $0.03 \%$ chitosan with $0.4 \%$ essential oil at $\mathrm{pH} 5.5$ was not significantly different, but in comparison with the $0.4 \%$ essential oil emulsion $(90.04 \%$ and $95 \%)$ or the $0.03 \%$ water-soluble chitosan $(65.26 \%$ and $61.83 \%$ ) alone, the chitosan and oil at $\mathrm{pH} 7.4$ and 8.5 had a synergistic antibacterial effect on S. aureus, with inhibition rates of $99.48 \%$ and $97.46 \%$, respectively. Moreover, in comparison with the $0.4 \%$ essential oil emulsion $(78.11 \%, 92.70 \%$, and $71.29 \%)$ or the $0.03 \%$ water-soluble chitosan $(76.04 \%$, $62.61 \%$, and $66.06 \%$ ) groups, the chitosan and oil at $\mathrm{pH} 5.5,7.4$, and 8.5 had significant synergistic antibacterial effects on $E$. coli, and the values were $91.68 \%, 99.06 \%$, and $95.06 \%$, respectively (Table 6). Despite the differences between the gram-positive and gram-negative species, the mixture of $0.03 \%$ water-soluble chitosan and the $0.4 \%$ essential oil emulsion at $\mathrm{pH} 7.4$ had the highest antibacterial effect on both $S$. aureus and E. coli. In comparison with the total bacterial count of the control group, the values were 2.40 and $2.26 \log \mathrm{CFU} / \mathrm{mL}$ lower (Table 4). Additionally, in comparison with the $0.4 \%$ essential oil emulsion and $0.03 \%$ water-soluble chitosan individually, the effects of this mixture in reducing the total bacterial counts of $S$. aureus were 1.8 and 4.6 times higher, respectively, and for E. coli were 2.2 and 4.8 times higher, respectively (Tables 3 and 4 ). The results showed that the mixture had significantly enhanced synergistic antibacterial effects on $S$. aureus and E. coli. The results of this study are similar to those of Feyziglu et al., who investigated the synergistic antibacterial activities of chitosan nanoparticles loaded with summer savory essential oil against S. aureus and E. coli O157:H7. However, the mixture's exact mechanism of action remains unclear [21]. The essential oil emulsion can enhance antibacterial synergy with water-soluble chitosan in neutral solution. This is not attributable to a specific compound or mechanism, but due to the presence of various chemical compounds with different structures in the pomelo peel essential oil [21]. In fact, the essential oils affect bacterial cells through different antimicrobial mechanisms, including attack on the phospholipid bilayer of the cellular membrane, disruption of enzyme systems, damage to the genetic material in the bacteria, and formation of fatty acid hydroperoxidase induced by the oxygenation of unsaturated fatty acids [7].

\section{Materials and Methods}

\subsection{Plant Material and Isolation of Essential Oils}

Pomelo (Citrus grandis [L.] Osbeck cv. Matou Wentan) was purchased from the Taiwan Huadong Fruit and Vegetable Producers' Cooperative. Essential oil was obtained from the fresh peel by using the method described by Fadel et al. with minor modifications [30]. The albedo of fresh pomelo peel was removed, the flavedo layer $(1,000 \mathrm{~g})$ was cut into small pieces by using a food processor (Cuisinart DLC-7 Super Pro, Japan), and the essential oil was obtained using a steam distillation device (KC-30, Kou Chou Instrument Co., Ltd, Taipei City, Taiwan) for $3 \mathrm{~h}$. The steam, containing the essential oil, was passed through a cooling system to condense it to form a liquid, and then the essential oil and water were separated. Afterward, the oil was dried over anhydrous sodium sulphate and stored in dark vials at $4{ }^{\circ} \mathrm{C}$ until analysis. 


\subsection{Preparation of Essential Oil Emulsions at Different Homogenizer Speeds}

The pomelo peel essential oil obtained through steam distillation was diluted with $1 \%(v / v)$ Tween 20 aqueous solution to $20 \%(v / v)$ essential oil. This mixture was homogenized using a high-speed emulsion homogenizer (Ultra-Turrax T-25; Janke \& Kunkel, IKA-Labortechnik, GmbH Co., Staufen, Germany) at $0,13,500$, and $24,000 \mathrm{rpm}$, for $0.5 \mathrm{~min}$, yielding a $20 \%(v / v)$ essential oil emulsion. A $0.2 \mu \mathrm{m}$ filter membrane was used for degerming (Gelman Sciences, Ann Arbor, MI, USA), and the essential oil emulsions were diluted with sterile $1 \%(v / v)$ Tween 20 solution to different concentrations to determine antibacterial activity.

\subsection{Preparation of Water-Soluble Chitosan}

Chitosan $(\mathrm{DA}=25 \%$ ) was purchased from Ohka Enterprises (Kaohsiung City, Taiwan). Water-soluble chitosan was prepared according to the methods described by Mima et al. and Kubota and Eguchi, with minor modifications [31,32]. The chitosan was added to $40 \%(w / w) \mathrm{NaOH}$ solution at a ratio of 1:10 and boiled for $4 \mathrm{~h}$. After being washed in deionized water to achieve neutrality, the chitosan was treated again in the alkaline solution for further deacetylation; thus, a highly deacetylated chitosan product was obtained with a $93.0 \%$ DA. The deacetylated chitosan product $(0.3 \mathrm{~g})$ was dissolved in $30 \mathrm{~mL}$ of $1 \%(w / w)$ aqueous acetic acid, mixed with $40 \mathrm{~mL}$ of $80 \%(w / w)$ methanol, and the desired amount $(0.18 \mathrm{~mL})$ of acetic anhydride was added. After stirring at room temperature for $5 \mathrm{~h}, 1.0 \mathrm{M}, \mathrm{NaOH}$ was added up to $\mathrm{pH} 8.0$ to stop the reaction. Finally, the reaction mixture was dialyzed against deionized water for 3 days and then lyophilized to powder form to determine the degree of $N$-acetylation of the chitosan.

\subsection{Preparation of Chitosan and Pomelo Peel Essential Oil Emulsion}

Sterility control of essential oils and chitosan was performed using the membrane filter method of Owlia et al., with some modifications [33]. To prepare a chitosan and pomelo peel essential oil emulsion, sterilized tryptic soy broth (TSB, Difco Laboratories, Sparks, MD, USA) was added to the prepared water-soluble chitosan on a sterile console, vibrated in a $75{ }^{\circ} \mathrm{C}$ water bath for $6 \mathrm{~h}$ to dissolution, and filtered by air exhaust through $0.4 \mu \mathrm{m}$ and $0.2 \mu \mathrm{m}$ filter membranes in turn, yielding TSB with chitosan at different concentrations $(0,0.01 \%(w / v), 0.03 \%(w / v), 0.05(w / v)$, and $0.1 \%(w / v))$. Subsequently, $0.2 \mathrm{~mL}$ of an essential oil emulsion (prepared through 24,000 rpm homogenization and $0.2 \mu \mathrm{m}$ filtration) was added to a spiral test tube with $9.7 \mathrm{~mL}$ of TSB. The concentrations of essential oil in the test tube were $0.1 \%(v / v), 0.2 \%(v / v)$, and $0.4 \%(v / v)$. Finally, the emulsion was inoculated with $0.1 \mathrm{~mL}$ of activated bacteria solution (S. aureus or E. coli) for antibacterial activity analysis. The control group contained only chitosan (concentrations were $0,0.01 \%(w / v), 0.03 \%(w / v), 0.05(w / v)$, and $0.1 \%$ $(w / v))$, instead of the essential oil emulsion.

\subsection{Preparation of Emulsion of Chitosan of Different $p H$ and Essential Oil}

To prepare an emulsion of chitosan of different $\mathrm{pH}$ and essential oil, $1.0 \mathrm{~N} \mathrm{HCl}$ and $1.0 \mathrm{~N} \mathrm{NaOH}$ were added to approximately $30.0 \mathrm{~g}$ of TSB, and deionized water was added to reach a volume of $1000 \mathrm{~mL}$; the $\mathrm{pH}$ was adjusted to $5.5,7.4$, and 8.5, respectively. The mixtures were sterilized at $121^{\circ} \mathrm{C}$ for $15 \mathrm{~min}$ and added to water-soluble chitosan to prepare TSB with $0.03 \%(w / v)$ chitosan. The preparation method described in Section 3.4 was employed. Afterward, the TSB with chitosan was mixed with $0.2 \mathrm{~mL}$ of an essential oil emulsion (prepared through 24,000 rpm homogenization and $0.2 \mu \mathrm{m}$ filtration), and the essential oil concentration was $0.4 \%(v / v)$. Finally, antibacterial activity analysis was conducted. Samples with only $0.03 \%(w / v)$ water-soluble chitosan or $0.4 \%(v / v)$ essential oil emulsion were used as control groups. In addition, $0.2 \%(w / v)$ water-soluble chitosan was prepared in TSB of different $\mathrm{pH}$ values for zeta potential analysis. 


\subsection{Chemical Analyses}

\subsubsection{GC-MS}

To an essential oil sample of approximately $0.05 \mathrm{~g}$, n-hexane was added to a volume of $5 \mathrm{~mL}$, and GC-MS was used for qualitative analysis of the essential oil composition. The qualitative analysis of the sample was performed using the method described by Deba et al. and Hosni et al., with minor modifications [17,34]. GC-MS analyses were performed on an HP 6890 (II) gas chromatograph interfaced with an HP 5973 mass spectrometer (Agilent Technologies, Palo Alto, CA, USA) with electron impact ionization $(70 \mathrm{eV})$. A DB-5 capillary column $(30 \mathrm{~m} \times 0.25 \mathrm{~mm}, 0.3 \mu \mathrm{m}$ film thickness, Agilent Technologies, Folsom, CA, USA) was used. The oven temperature was held at $50{ }^{\circ} \mathrm{C}$ for 2 min and then increased at $5{ }^{\circ} \mathrm{C} / \mathrm{min}$ to $250{ }^{\circ} \mathrm{C}$. The carrier gas, helium, was injected at a flow rate of $1.0 \mathrm{~mL} / \mathrm{min}$. The scan time and mass range were $1 \mathrm{~s}$ and $41-400 \mathrm{~m} / \mathrm{z}$, respectively. The data were recorded as the average of three analyses. Matching of Kovat's indices [35] and matching of mass spectra were performed for composition identification. The mass spectra used for reference were obtained from the National Institute of Standards and Technology and Wiley databases.

\subsubsection{Gas Chromatography (GC)}

To an essential oil sample (0.6 g) or each essential oil standards (0.02 g) ( $\alpha$-pinene, $\beta$-pinene, myrcene, limonene, $\gamma$-terpinene, cis-linalool oxide (f), cis-linalool oxide (f) linalool, $\alpha$-terpineol, neryl acetate and geranyl acetate), n-hexane was added to a volume of $2.0 \mathrm{~mL}$, and $0.8 \mathrm{~mL}$ of the essential oil sample solution was mixed with n-hexyl alcohol at an appropriate concentration (n-hexyl alcohol was added to $0.13 \mathrm{~g}$ of $\mathrm{n}$-hexane to a volume of $20 \mathrm{~mL}$ ) to establish an internal standard. The quantitative analysis of each sample was performed using the method described by Hosni et al. and Mohammadi et al., with minor modifications [17,36]. GC analyses were conducted on a Shimadzu GC-14 gas chromatograph (Shimadzu Corporation, Kyoto, Japan), equipped with a flame ionization detector, and a Shimadzu C-R6A chromatopac integraph (Shimadzu Corporation, Kyoto, Japan). An Equity-5 nonpolar column $(60 \mathrm{~m} \times 0.25 \mathrm{~mm}, 0.25 \mu \mathrm{m}$ film thickness) was used. The column temperature was programmed to rise from 75 to $200{ }^{\circ} \mathrm{C}$ at a rate of $2{ }^{\circ} \mathrm{C} / \mathrm{min}$. The injector and detector temperature were set at $250^{\circ} \mathrm{C}$. The flow of the carrier gas $\left(\mathrm{N}_{2}\right)$ was $50 \mathrm{~mL} / \mathrm{min}$. The injection volume for all samples was $0.5 \mu \mathrm{L}$ of diluted oil in n-hexane (Merck KGaA, Darmstadt, Germany). The data were recorded as the average of three analyses.

\subsubsection{Determination of the Degree of $N$-Acetylation in Water-Soluble Chitosan}

The degree of $N$-acetylation in water-soluble chitosan was determined through high-performance liquid chromatography, using the method described by Niola et al. with modifications [37]. A $10 \mathrm{mg}$ sample was placed in a vacuum hydrolysis tube with $0.5 \mathrm{~mL}$ of $12 \mathrm{M} \mathrm{H}_{2} \mathrm{SO}_{4}$ and a standard mixture $(6.9 \mathrm{mg}$ of oxalic acid dihydrate and $0.25 \mathrm{~mL}$ of propionic acid dissolved in $100 \mathrm{~mL}$ of deionized water). The tube was closed and placed in a circulating heating bath at $155{ }^{\circ} \mathrm{C}$, and after a $1 \mathrm{~h}$ reaction, the tube was placed in ice water for $30 \mathrm{~min}$, and then allowed to reach room temperature. The mixture was completed with $10 \mathrm{~mL}$ of deionized water and filtered through a $0.2 \mu \mathrm{m}$ membrane. Ten microliters of this solution were directly injected into a Synergi $\mathrm{C}_{18}$ column $(4.6 \times 250 \mathrm{~mm}$, particle size, $4 \mu \mathrm{m}$; Phenomenex, Torrance, CA, USA) in order to analyze the amount of acetic acid. The sample was analyzed in triplicate. The amount of liberated acetyl groups ( $\mathrm{mx}$ ) was calculated using the following equation:

$$
\mathrm{mx}=\mathrm{K} \times(\mathrm{Ax} / \mathrm{Ais}) \times \mathrm{Mis}
$$

where $\mathrm{K}$ is the response factor; $\mathrm{Ax}$ and Ais are the areas of the acetic and propionic acid peaks, respectively, as the internal standard; and Mis is the amount of the internal standard. The percentage of $N$-acetylation was calculated using the following equation:

$$
\text { degree of } N \text {-acetylation }(\%)=(161 \mathrm{X} / 60-42 \mathrm{X}) \times 100
$$


where $\mathrm{X}=\mathrm{mx} / \mathrm{M}^{\prime} ; \mathrm{M}^{\prime}=\mathrm{M}-\mathrm{mi}$ ( $\mathrm{mi}=$ mass of inorganic material including curd protein and ash content); 161 is the mole weight of a 2-amino-2-deoxy-D-glucose unit; and 60 is the mole weight of the acetic acid.

\subsection{Zeta Potential Analysis of Chitosan in TSB}

The zeta potential in water-soluble chitosan was determined with a Zetasizer (Nano ZSP, Malvern Instruments Corp., Worcestershire, UK), using the method described by Gohtani and Yamano with modifications [38]. The zeta potential measurements were performed in deionized water, which acted as a dispersant, by using a disposable folded capillary cell with the electrodes at $25^{\circ} \mathrm{C}$ and an applied voltage of $150 \mathrm{~V}$. The data were recorded as the average of three analyses.

\subsection{Assays for Antibacterial Activity}

\subsubsection{Species Culture}

The preparation of bacteria was performed using the method described by Friendman et al., with some modifications [39]. E. coli (CCRC 10674) and S. aureus (CCRC 12652) were purchased from the Bioresource Collection and Research Center of the Food Industry Research and Development Institute (Hsinchu City, Taiwan). The species culture was prepared according to the method described by Carson et al., with some modifications [40]. The bacteria from 1 inoculation loop were cultured in a spiral test tube with TSB at $37^{\circ} \mathrm{C}$ for $6 \mathrm{~h}$. The bacterial solution absorbance value was $600 \mathrm{~nm}$, the detected value was 0.33 , and the bacterial count was $10^{9} \mathrm{CFU} / \mathrm{mL}$, which was reduced through dilution with TSB to $10^{6} \mathrm{CFU} / \mathrm{mL}$.

\subsubsection{Antibacterial Activity}

The antibacterial activity tests were performed using the broth dilution method of Kim and Shin, with some modifications [41]. Samples were prepared before the antibacterial activity was analyzed. Essential oil emulsions and TSB with various chitosan concentrations $(0,0.01 \%(w / v), 0.03 \%(w / v)$, $0.05(w / v)$, and $0.1 \%(w / v)$ were prepared according to the previously described procedures. To a spiral test tube with $9.7 \mathrm{~mL}$ of TSB, $0.1 \mathrm{~mL}$ of the $10^{6} \mathrm{CFU} / \mathrm{mL}$ bacterial solution and $0.2 \mathrm{~mL}$ of an essential oil emulsion were added; the essential oil concentrations in the tube were $0.4 \%(v / v), 0.2 \%(v / v)$, and $0.1 \%$ $(v / v)$. The control group was $1 \%(v / v)$ Tween 20 solution. After $10 \mathrm{~h}$ of culture at $37^{\circ} \mathrm{C}$, the samples were diluted with $0.85 \%(w / v) \mathrm{NaCl}$ in tryptic soy agar (Difco Laboratories, Sparks, MD, USA) and cultured at $37^{\circ} \mathrm{C}$ for $24 \mathrm{~h}$, and the colony counts in various diluted bacterial solution culture dishes were determined (only 30 to 300 colony counts were recorded in the experiments). Each sample was analyzed in triplicate.

\subsubsection{Determination of Minimum Inhibitory Concentration}

The minimum inhibitory concentration was determined according to the method described by Skandamis et al., with minor modifications [42]. The essential oil emulsions of pomelo peel prepared under different homogenization conditions and S. aureus or E. coli were cultured at $37^{\circ} \mathrm{C}$ for $24 \mathrm{~h}$ for antibacterial activity testing. The data were recorded as the average of three analyses. The essential oil concentration and residual bacterial count were plotted to obtain the regression curve, and the minimum essential oil concentration (x) for inhibiting $90 \%$ of the bacterial count (y) was obtained according to the following regression equation:

$$
\begin{aligned}
& y=a x+b \\
& y: \text { Residual bacterial count }(\log C F U / m L) \\
& x: \text { Essential oil concentration }(\%)
\end{aligned}
$$




\subsection{Statistical Analysis}

Analysis of variance for the results of the aforementioned experiments was performed using Statistical Analysis Systems [43]. Multiple mean comparisons were conducted using Duncan's multiple range test.

\section{Conclusions}

Use of essential oils and chitosan in the food industry is limited due to their poor solubility in water. In this study, a mixture soluble in a neutral water solution ( $\mathrm{pH}$ 7.4) was successfully prepared through the homogenization of the essential oil and deacetylated water-soluble chitosan, which have strong synergetic antibacterial effects on food pathogens. The reduction in total bacterial counts of a mixture of a $0.4 \%$ pomelo peel essential oil emulsion and $0.03 \%$ water-soluble chitosan in a neutral water solution on S. aureus was higher than that of the $0.4 \%$ essential oil emulsion or $0.03 \%$ water-soluble chitosan alone by approximately 1.8 and 4.6 times, respectively, and, for E. coli, by approximately 2.2 and 4.8 times, respectively. The composition of the essential oil of Taiwan Matou pomelo peel, obtained through steam distillation, was analyzed through GC-MS. A total of 33 compounds were identified, and the main constituent was limonene $(940.07 \mathrm{mg} / \mathrm{g})$. The results showed that a pomelo peel essential oil emulsion homogenized at $24,000 \mathrm{rpm}$ had a stronger inhibitory effect on S. aureus and E. coli than unhomogenized essential oil, with the MIC value being 1.9 times lower. Therefore, this study suggests using a mixture of emulsified pomelo peel oil and water-soluble chitosan to develop a novel natural food preservative, which could prevent the growth of pathogens in foods and extend their shelf life. Additionally, this study indicates that the processability of food, as well as the economic value of the byproducts of the Taiwan Matou pomelo and chitosan, could be increased.

Acknowledgments: The authors would like to thank Prof. Lang-Bang Hung and Jenn-Shou Tsai (Department of Food Science, National Taiwan Ocean University, Taiwan) for providing instruments and equipment, as well as instructions for operating analytic instruments. This research did not receive any specific grant from funding agencies in the public, commercial, or not-for-profit sectors.

Author Contributions: Guan-Wen Chen and Yu-Hsin Lin contributed equally to this work as co-first authors. Guan-Wen Chen and Yu-Hsin Lin proposed and designed the experiment. Guan-Wen Chen, Yu-Hsin Lin, Chia-Hua Lin, and Hsiao-Chin Jen analyzed the data and wrote the manuscript. Yu-Hsin Lin revised the manuscript and was responsible for the supervision of the overall research.

Conflicts of Interest: The authors declare no conflict of interest.

\section{References and Note}

1. Tian, J.; Zeng, X.; Feng, Z.; Miao, X.; Peng, X.; Wang, Y. Zanthoxylum mold Rehd. Essantial oil as a potential natural preservative in management of Aspergillus flarus. Ind. Crop. Prod. 2014, 60, 151-159. [CrossRef]

2. Tsai, H.L.; Chang, S.K.C.; Chang, S.J. Antioxidant content and free radical scavenging ability of fresh red pomelo [Citrus grandis (L.) Osbeck] juice and freeze-dried products. J. Agric. Food Chem. 2007, 55, $2867-2872$. [CrossRef] [PubMed]

3. Yearly Report of Taiwan's Agriculture 2003: Index of Agricultural Production, 5. Fruits, (4) Pai Pomelos, Liuchengs. Council of Agriculture Executive Yuan R.O.C.: 37 Nanhai Road, Taipei, Taiwan 10014, 2009.

4. Anwar, F.; Naseer, R.; Bhanger, M.I.; Ashraf, S.; Talpur, F.N.; Aladedunye, F.A. Physico-chemical characteristics of citrus seeds and seed oils from Pakistan. J. Am. Oil Chem. Soc. 2008, 85, 321-330. [CrossRef]

5. Senevirathne, M.; Jeon, Y.J.; Ha, J.H.; Kim, S.H. Effective drying of citrus by-product by high speed drying: A novel drying technique and their antioxidant activity. J. Food Eng. 2009, 92, 157-163. [CrossRef]

6. Inouye, S.; Yamaguchi, H.; Takizawa, T. Screening of the antibacterial effects of a variety of essential oils on respiratory tract pathogens, using a modified dilution assay method. J. Infect. Chemother. 2001, 7, 251-254. [CrossRef] [PubMed]

7. Burt, S. Essential oils: Their antibacterial properties and potential applications in foods-A review. Int. J. Food Microbiol. 2004, 94, 223-253. [CrossRef] [PubMed] 
8. Bhargava, K.; Conti, D.S.; da Rocha, S.R.; Zhang, Y. Application of an oregano oil nanoemulsion to the control of foodborne bacteria on fresh lettuce. Food Microbiol. 2015, 47, 69-73. [CrossRef] [PubMed]

9. Moghimi, R.; Ghaderi, L.; Rafati, H.; Aliahmadi, A.; McClements, D.J. Superior antibacterial activity of nanoemulsion of Thymus daenensis essential oil against E. coli. Food Chem. 2016, 194, 410-415. [CrossRef] [PubMed]

10. Alves, N.M.; Mano, J.F. Chitosan derivatives obtained by chemical modifications for biomedical and environmental applications. Int. J. Biol. Macromol. 2008, 43, 401-414. [CrossRef] [PubMed]

11. Muzzarelli, R.A.A.; Muzzarelli, C.; Tarsi, R.; Miliani, M.; Gabbanelli, F.; Cartolari, M. Fungistatic activity of modified chitosans against Saprolegnia parasitica. Biomacromolecules 2001, 2, 165-169. [CrossRef] [PubMed]

12. Helander, I.M.; Nurmiaho-Lassila, E.L.; Ahvenainen, R.; Rhoades, J.; Roller, S. Chitosan disrupts the barrier properties of the outer membrane of Gram-negative bacteria. Int. J. Food Microbiol. 2001, 71, 235-244. [CrossRef]

13. Chen, Y.M.; Chung, Y.C.; Wang, L.W.; Chen, K.T.; Li, S.Y. Antibacterial properties of chitosan in waterborne pathogen. J. Environ. Sci. Health Part A 2001, 37, 1379-1390. [CrossRef]

14. Omura, Y.; Shigemoto, M.; Akiyama, T.; Saimoto, H.; Shigemasa, Y.; Nakamura, I.; Tsuchido, T. Antimicrobial activity of chitosan with different degrees of acetylation and molecular weights. Biocontrol. Sci. 2003, 8, 25-30. [CrossRef]

15. Marangon, C.A.; Martins, V.C.A.; Leiteb, P.M.F.; Santos, D.A.; Nitschke, M.; Plepis, A.M.G. Chitosan/gelatin/ copaiba oil emulsion formulation and its potential on controlling the growth of pathogenic bacteria. Ind. Crop. Prod. 2017, 99, 163-171. [CrossRef]

16. Minh Tu, N.T.; Thanh, L.X.; Une, A.; Ukeda, H.; Sawamura, M. Volatile constituents of Vietnamese pomelo, orange, tangerine and lime peel oils. Flavour Frag. J. 2002, 17, 169-174. [CrossRef]

17. Hosni, K.; Zahed, N.; Chrif, R.; Abid, I.; Medfei, W.; Kallel, M.; Brahim, N.B.; Sebei, H. Composition of peel essential oils from four selected Tunisian Citrus species: Evidence for the genotypic influence. Food Chem. 2010, 123, 1098-1104. [CrossRef]

18. Smith-Palmer, A.; Stewart, J.; Fyfe, L. Antimicrobial properties of plant essential oils and essences against five important food-borne pathogens. Lett. Appl. Microbiol. 1998, 26, 118-122. [CrossRef] [PubMed]

19. Zhang, Z.; Vriesekoop, F.; Yuan, Q.; Liang, H. Effects of nisin on the antimicrobial activity of D-limonene and its nanoemulsion. Food Chem. 2014, 150, 307-312. [CrossRef] [PubMed]

20. Radhakrishnan, Y.; Gopal, G.; Lakshmanan, C.C.; Nandakumar, K.S. Chitosan nanoparticles for generating novel systems for better applications: A review. J. Mol. Genet. Med. 2015. [CrossRef]

21. Feyzioglu, G.C.; Tornuk, F. Development of chitosan nanoparticles loaded with summer savory (Satureja hortensis L.) essential oil for antimicrobial and antioxidant delivery applications. LWT-Food Sci. Technol. 2016, 70, 104-110. [CrossRef]

22. Hongpattarakere, T.; Riyaphan, O. Effect of deacetylation conditions on antimicrobial activity of chitosans prepared from carapace of black tiger shrimp (Penaeus monodon). Songklanakarin J. Sci. Technol. 2008, 30, 1-9.

23. Hoque, M.; Bari, M.L.; Juneja, V.K.; Kawamoto, S. Antimicrobial activity of cloves and cinnamon extracts against food borne pathogens and spoilage bacteria, and inactivation of Listeria monocytogenes in Ground chicken meat with their essential oils. Rep. Nat. Food Res. Inst. 2008, 72, 9-21.

24. Canillac, N.; Mourey, A. Effects of several environmental factors on the anti-Listeria monocytogenes activity of an essential oil of Picea excelsa. Int. J. Food Microbiol. 2004, 92, 95-103. [CrossRef] [PubMed]

25. Juven, B.J.; Kanner, J.; Schved, F.; Weisslowicz, H. Factors that interact with the antibacterial action of thyme essential oil and its active constituents. J. Appl. Microbiol. 1994, 76, 626-631. [CrossRef]

26. Sikkema, J.; de Bont, J.; Poolman, B. Interactions of cyclic hydrocarbons with biological membranes. J. Biol. Chem. 1994, 269, 8022-8028. [PubMed]

27. Espina, L.; Gelaw, T.K.; de Lamo-Castellvi, S.; Pagán, R.; Garcia-Gonzalo, D. Mechanism of bacterial inactivation by (+)-limonene and its potential use in food preservation combined processes. PLOS ONE 2013, 8, e56769. [CrossRef] [PubMed]

28. Roller, S.; Covill, N. The antifungal properties of chitosan in laboratory media and apple juice. Int. J. Food Microbiol. 1999, 47, 67-77. [CrossRef]

29. Xie, W.; Xu, P.; Wang, W.; Liu, Q. Preparation and antibacterial activity of a water-soluble chitosan derivative. Carbohyd. Polym. 2002, 50, 35-40. [CrossRef] 
30. Fadel, H.; Marx, F.; El-Sawy, A.; El-Ghorab, A. Effect of extraction techniques on the chemical composition and antioxidant activity of Eucalyptus camaldulensis var. brevirostris leaf oils. Z. Lebensm. Unters. Forsch. 1999, 208, 212-216. [CrossRef]

31. Mima, S.; Miya, M.; Iwamoto, R.; Yoshikawa, S. Highly deacetylated chitosan and its properties. J. Appl. Polym. Sci. 1983, 28, 1909-1917. [CrossRef]

32. Kubota, N.; Eguchi, Y. Facile preparation of water-soluble $N$-acetylated chitosan and molecular weight dependence of its water-solubility. Polym. J. 1997, 29, 123-127. [CrossRef]

33. Owlia, P.; Saderia, H.; Rasooli, I.; Sefidkonc, F. Antimicrobial characteristics of some herbal oils on Pseudomonas aeruginosa with special reference to their chemical compositions. Iran. J. Pharm. Res. 2009, 8, 107-114.

34. Deba, F.; Xuan, T.D.; Yasuda, M.; Tawata, S. Chemical composition and antioxidant, antibacterial and antifungal activities of the essential oils from Bidens pilosa Linn. var. Radiata. Food Control 2008, 19, 346-352. [CrossRef]

35. Oliveira de Figueiredo, R.; Nakagawa, J.; Marques, M.O.M. Composition of coriander essential oil from Brazil. Acta Hortic. 2004, 629, 135-137. [CrossRef]

36. Mohammadi, A.; Sani, T.A.; Ameri, A.A.; Imani, M.; Golmakani, E.; Kamali, H. Seasonal variation in the chemical composition, antioxidant activity, and total phenolic content of Artemisia absinthium essential oils. Pharmacognosy Res. 2015, 7, 329-334.

37. Niola, F.; Basora, N.; Chornet, E.; Vidal, P.F. A rapid method for the determination of the degree of $\mathrm{N}$-acetylation of chitin-chitosan samples by acid hydrolysis and HPLC. Carbohyd. Res. 1993, 238, 1-9. [CrossRef]

38. Gohtani, S.; Yamano, Y.; Gohtani, S. Stability and zeta potential of soysaponin I emulsion. Nippon Nog Kag Kaish 1990, 64, 139-144. [CrossRef]

39. Friendman, M.; Henika, P.R.; Mandrell, R.E. Bactericidal activities of plant essential oils and some of their isolated constituents against Campylobacter jejuni, Escherichia coli, Listeria monocytogenes, and Salmonella enterica. J. Food Protect. 2002, 65, 1545-1560. [CrossRef]

40. Carson, C.F.; Mee, B.J.; Riley, T.V. Mechanism of action of Melaleuca alternifolia (tea tree) oil on Staphylococcus aureus determined by time-till, lysis, leakage, and salt tolerance assays and electron microscopy. Antimicrob. Agents Chemother. 2002, 46, 1914-1920. [CrossRef]

41. Kim, Y.S.; Shin, D.H. Volatile constituents from the leaves of Callicarpa japonica Thunb. and their antibacterial activities. J. Agr. Food Chem. 2004, 52, 781-787. [CrossRef] [PubMed]

42. Skandamis, P.; Koutsoumanis, K.; Fasseas, K.; Nychas, G.J.E. Inhibition of oregano essential oil and EDTA on Escherichia coli O157:H7. Ital. J. Food Sci. 2001, 13, 65-75.

43. SAS Institute Inc. SAS user's guide: Statistics; SAS Institute Press: Cary, NC, USA, 1988; p. 584.

Sample Availability: Samples of the compounds 1-3, 5, 7, 8, 10, 11, 17, 25, 26 are available from the authors.

(C) 2018 by the authors. Licensee MDPI, Basel, Switzerland. This article is an open access article distributed under the terms and conditions of the Creative Commons Attribution (CC BY) license (http:/ / creativecommons.org/licenses/by/4.0/). 